\title{
Bergaueria perata Prantl, 1945 from the Silurian of Cape George, Nova Scotia
}

\author{
R. K. Pickerill \\ Department of Geology, University of New Brunswick, Fredericton \\ New Brunswick E3B 5A3, Canada
}

Date Received March 24, 1989

Date Accepted June 16, 1989

\begin{abstract}
The ichnogenus Bergaueria is formally documented for only the second time from Silurian strata, from the Silurian (prelate Ludlow) of Cape George, Nova Scotia, and for the first time from eastern Canada. Specimens are assigned to $B$. perat $a$, thus representing the first recording of the ichnospecies in Silurian strata. The excellent preservation of several specimens, combined with a review of previously described examples, permits a revised diagnosis of $B$. perata to include the common, almost universal, presence of concentric ornamentation.
\end{abstract}

La présente documentation formelle de l'ichnogenre Bergaueria, dans le Silurien (avant le Ludlow tardif) de Cape George, en Nouvelle-Ecosse, est seulement la seconde dans des strates siluriennes et la toute première dans l'Est du Canada. Les spécimens sont rapportés à $B$. perata, dont la présence au sein de strates siluriennes est de ce fait notée pour la première fois. L'excellente conservation de plusieurs spécimens, combinée à une révision des exemples déjà décrits, permet d'inclure la présence répandue, quasi universelle, d'une ornementation concentrique dans une nouvelle diagnose de $B$. perata.

[Traduit par le joumal]

\section{INTRODUCTION}

The ichnotaxonomy of single-entrance, plug-shaped, softsubstrate trace fossils has recently been elegantly reviewed by Pemberton et al. (1988). These authors demonstrated that, following literally decades of confusion, all such trace fossils could be reasonably assigned to essentially five ichnogenera, namely Bergaueria Prantl, 1945, Conichnus Myannil, 1966, Conostichus Lesquereux, 1876, Dolopichnus Alpert and Moore, 1975 and Astropolichnus Crimes and Anderson, 1985, with minor forms encompassed within Calycraterion Karaszewski, 1971, Margaritichnus Bandel, 1973 or Mammillichnis Chamberlain, 1971. With respect to the ichnogenus Bergaueria, the subject of this contribution, Pemberton et al. (1988) recognized four distinctive ichnospecies, $B$. perata Prantl, 1945, B. langi (Hallam, 1960), B. radiata Alpert, 1973 and B. hemispherica Crimes et al., 1977.

Somewhat surprisingly Bergaueria, although previously reported from strata of earliest Cambrian to Pleistocene age (see Crimes, 1987; Pemberton and Jones, 1988), has only once been formally documented from Silurian strata. This recording is by Narbonne (1984) from the Upper Silurian (Ludlow) Leopold Formation of arctic Canada. Because of their generally poor preservation, specimens recorded by Narbonne (1984) were only identified at the ichnogeneric level, though at an earlier date in his unpublished thesis (Narbonne, 1981) he did tentatively compare them to $B$. radiata.
In this paper, Bergaueria is formally recorded for only the second time from Silurian strata and certainly for the first time in any Phanerozoic sequence from eastem Canada. Specimens described herein can clearly be allocated to $B$. perat $a$ and therefore this recording also represents the first definitive occurrence of the ichnospecies in Silurian strata. Finally, the excellent preservation of several specimens permits a revised and expanded diagnosis of $B$. perata as recently proposed by Pemberton et al. (1988).

\section{GEOLOGIC SETTING}

Material described here was collected in 1984 from School Brook Cove-East on the north coast of Cape George, the peninsula forming the prominent northeastern corner of mainland Nova Scotia between Northumberland Strait and St. Georges Bay (Figs. 1, 2). Cape George is underlain by Hadrynian metasedimentary and metavolcanic rocks and, predominantly, unmetamorphosed and lithologically variable Devonian to Carboniferous strata (Fig. 1). At the extreme northern end of the peninsula, at and between Cormorant Cliff and School Brook Cove-East, occurs a complex fault-bounded and, regionally, a stratigraphically enigmatic sequence of Ordovician to Lower Devonian strata. These strata are cut and bounded by major eastwest striking normal, strike-slip and thrust faults and numerous and multidirectional minor faults. Boucot et al. (1974) referred to the entire sequence as the "Lower Palcozoic Fault Complex," 


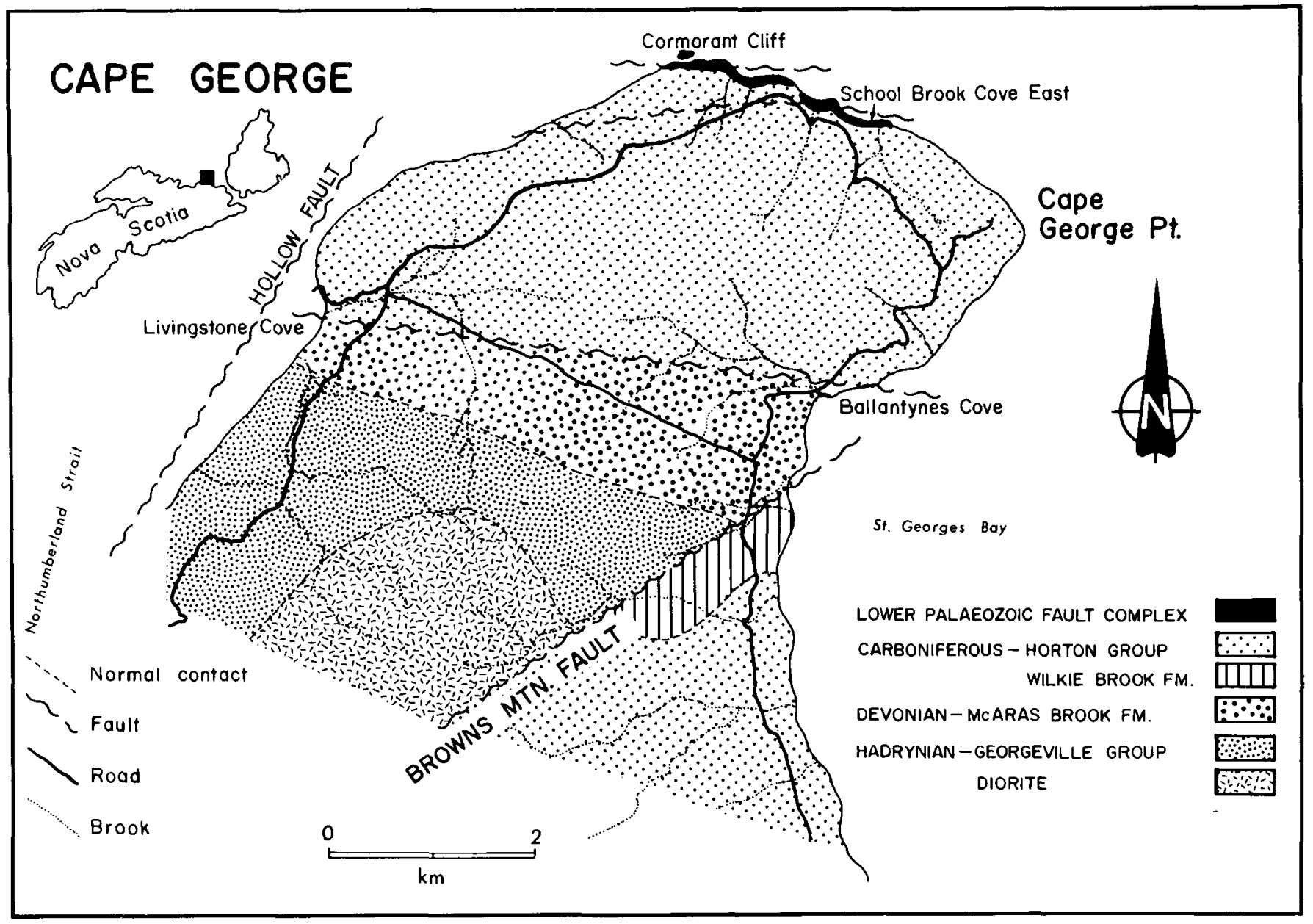

Fig. 1. Location map and generalized geology of Cape George, northeast mainland Nova Scotia. Specimens discussed hercin are from School Brook Cove-East.

a terminology which is adopted herein (Fig. 1). These authors also provided detailed stratigraphic columns and structural maps of the complex.

The described material was collected from the Scolithus (Worm Tube) Quartzite (sic.) of Boucot et al. (1974 - their unit $\mathrm{S}_{2}$ ), estimated by these authors to be approximately $16 \mathrm{~m}$ in thickness. Brachiopods at the base of this unit indicate a Silurian age; however, its precise age cannot be ascertained. All that can be concluded is that it is one of the four units (in ascending stratigraphic order, units $\mathrm{S}_{1}-\mathrm{S}_{4}$ conclusive) that underlie upper Ludlow to lower Gedinnian strata and overlie Middle or Upper Ordovician brachiopod-bearing hornfelsed quartzites and associated intrusive hornblende diorites (Boucot et al., 1974).

At School Brook Cove-East the Scolithus Quartzite of Boucot et al. (1974) is exposed as a series of typically discontinuous, small and low-lying outcrops (Fig. 2). The specimens were collected from one such outcrop located in the intertidal zone. The outcrop is currently covered by storm-derived gravels but may subsequently be re-exposed at some future date.

Lithologically, the Scolithus Quartzite consists of interbeds of massive or parallel-laminated, clean, white to pinkish-white, medium-grained, 0.5 to $0.8 \mathrm{~m}$ thick quartzites and greyish-white, parallel- and cross-laminated silty quartzites up to $0.5 \mathrm{~m}$ in thickness. These latter interbeds exhibit many examples of the simple vertical to sub-vertical cylindrical trace fossil Skolithos Haldeman, 1840 in addition to the specimens of Bergaueria perata described herein.

\section{SYSTEMATIC PALICHNOLOGY}

Ichnogenus Bergaueria Prantl, 1945

\section{Bergaueria perata Prantl, 1945}

(Fig. 3a-d)

\section{Material}

A single slab possessing ten variably preserved specimens (numbered 1 to 10 in Fig. 3a); housed in the Geology Department, University of New Brunswick.

\section{Emended diagnosis}

Unlined or thinly lined Bergaueria, diameter slightly less than, equal to, or more typically greater than height; rounded lower end rarely exhibits faint radial ridges emanating from a central depression and a peripheral ridge; surface may be smooth but concentric ornamentation typically present (after Prantl, 


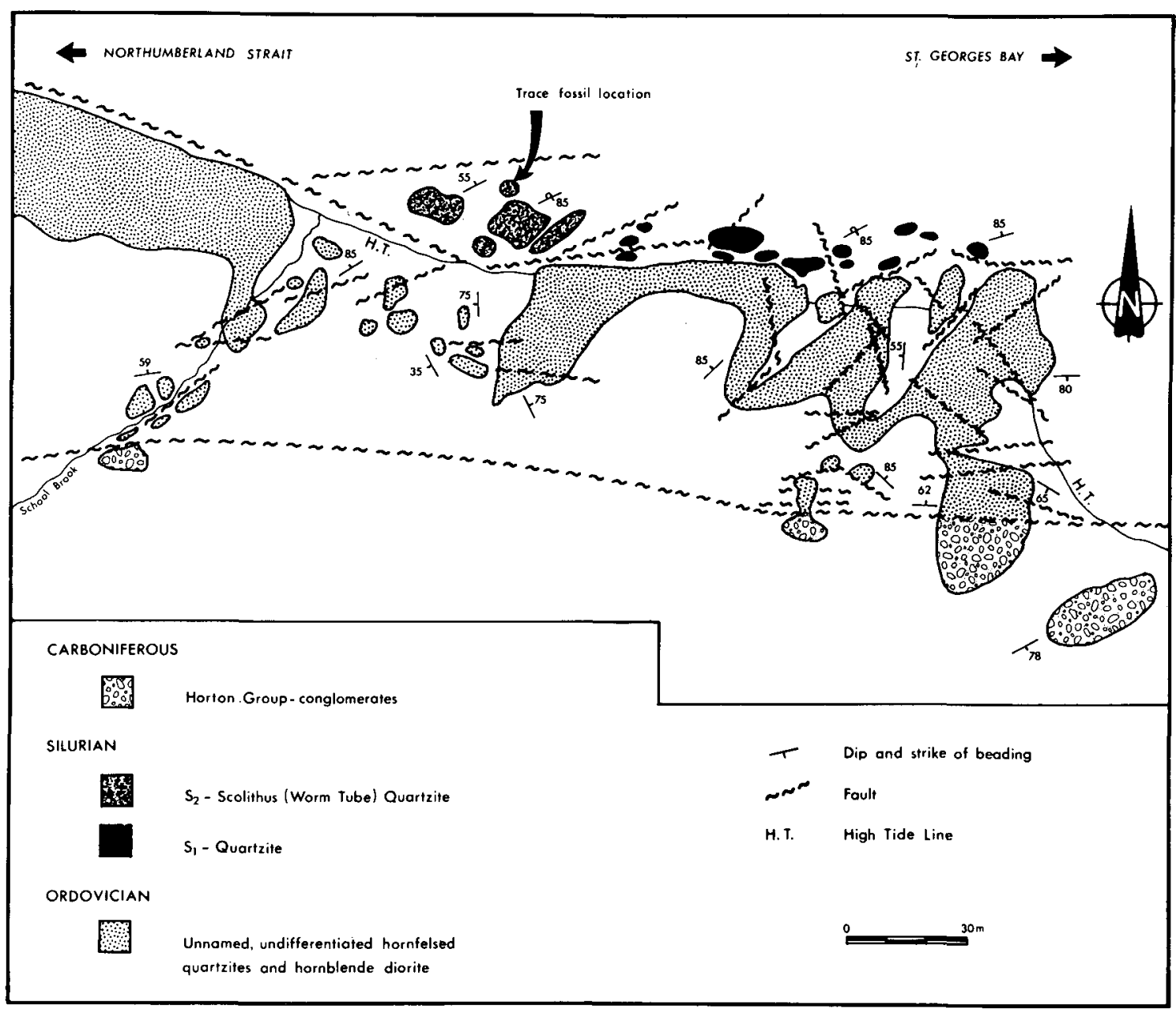

Fig. 2. Simplified geological map of School Brook Cove-East showing trace fossil location. Simplified greatly from Boucot $e t$ al. (1974, Plate 13).

1945; Crimes et al., 1977; Pemberton et al., 1988; Fillion and Pickerill, 1990).

\section{Description}

Specimens are preserved in convex hyporelief as ventrally flattened inverted hemispheres on the sole of a $10 \mathrm{~cm}$ thick, massive to parallel-laminated passing into cross-laminated, greyish-white silty quartzite. Of the ten specimens (referred to as 1 through 10 -see Fig. 3) three are essentially completely preserved $(1,2,3)$ and the remainder have been erosionally beheaded (9) or, because of the nature of the sample, are incomplete $(4-8,10)$.

In plan view, the complete specimens are circular to slightly sub-circular in shape with diameters of $3.7 \times 2.9(1), 4.1 \times 4.1$ (2) and $4.2 \times 4.2 \mathrm{~cm}(3)$ and respective depths of $1.9,1.8$ and $1.8 \mathrm{~cm}$. Specimen 9 (Fig. 2a) is $3.5 \mathrm{~cm}$ in diameter; assuming an essentially circular diameter for the incomplete examples, interpolated widths range from 3.9 (5) to $5.1 \mathrm{~cm}$ (7). Maximum depth, as noted, is $1.9 \mathrm{~cm}$ (1) but even in the incomplete specimens can confidently be ascertained to be considerably less, as little as 0.9 $\mathrm{cm}$ (4). Lower ends of the complete specimens are essentially flattened to gently rounded, symmetric $(1)$ or asymmetric $(2,3)$ and possess a small, 3 to $5 \mathrm{~mm}$ wide depression $(1,2)$ or slightly elevated protuberance (3). These connect with smooth bases which are unornamented and extend outward to slightly elevated almost peripheral and concentric ridges (Fig. 3). From these peripheral ridges the structures extend convexly downwards as vertically or very steeply inclined margins.

All specimens possess an extremely thin lining $(<1 \mathrm{~mm}$ thick) of pale brown mudstone which also veneers the basal bedding plane surface. From the basal peripheral ridge to the exposed uppermost portion of the specimens, the mudstone veneers exhibit variably but obviously developed concentric ornament (Fig. 3), which can also be recognized in the majority of the incomplete specimens. Burrow fill is massive and structureless.

\section{Remarks}

As recognized by Pemberton et al. (1988), ichnospecies of Bergaueria are differentiated primarily on the characteristics of the wall linings and distal terminations. Bergaueria langi is thickly walled, $B$. hemispherica lacks a terminal central depression and $B$. radiata displays prominent radial ornament around a single central depression. Clearly, therefore, the material here conforms best with $B$. perata and is regarded as conspecific.

Prantl $(1945,1946)$ observed that the diameter of $B$. perata (35 to $45 \mathrm{~mm}$ ) was about the same as the height, but subsequent 


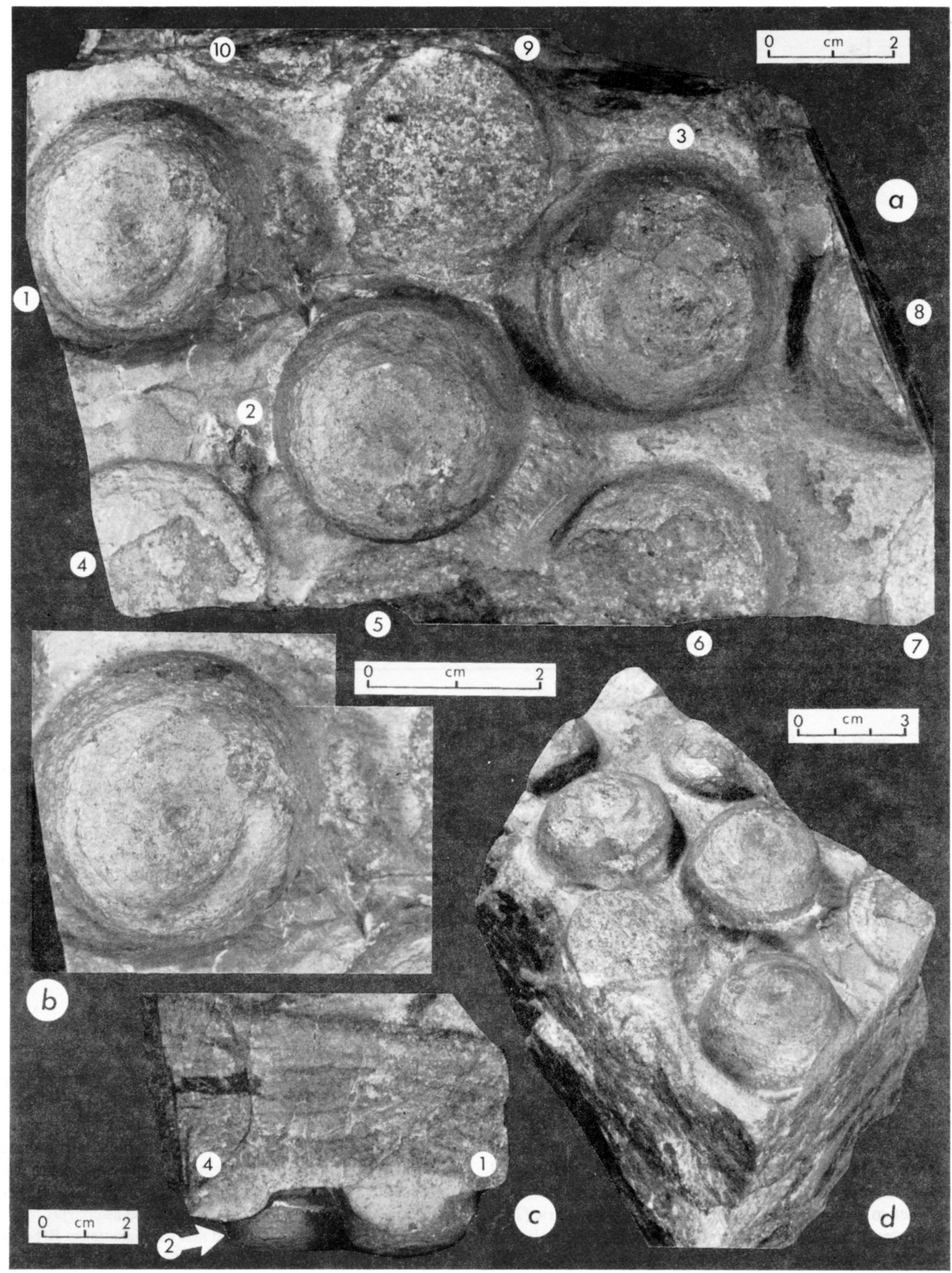


recordings have noted that it is typically greater than (e.g., Arai and McGugan, 1968; Crimes et al., 1977; Pemberton et al., 1988; Fillion and Pickerill, in press) or, in rare occurrences, slightly less than (e.g., Fürsich, 1974) the height. Specimens described here conform to the more typical case but this obvious variation is included in the emended diagnosis.

Most specimens described herein exhibit faint but welldefined concentric ornamentation; otherwise, walls are smooth. In their description and diagnosis of $B$. perata, Pemberton $e t$ al. (1988) do not indicate that the majority of previously described specimens of $B$. perata possess such ornament, even though it may be variably developed. Even the type material figured by Prantl $(1945,1946)$ possesses clearly defined concentric ornament in the majority of specimens, as does that figured and described by Radwanski and Roniewicz (1963), Arai and McGugan (1968), Alpert (1973), and Hakes (1976). Similarly, although not noted by Książkiewicz (1977), concentric ornament is clearly evident in his examples of $B$. prantli, subsequently questionably synonymized with $B$. perata by Pemberton $e t$ al. (1988). Even B. perata figured by Pemberton et al. (1988, p. 879, Fig. 5) displays concentric ornament. Thus, $B$. perata may be smooth, or, more typically, may possess concentric omament externally to the ventral and peripheral external ridge; the diagnosis of the ichnospecies is also emended accordingly.

The origin of the concentric ornament is somewhat enigmatic but may possibly reflect the ability of the producing organism to bodily contract and dilate (cf. Radwanski and Roniewicz, 1963), may be a result of compaction (cf. Arai and McGugan, 1968; Boyd, 1974), or may reflect laminae in the presumed surrounding mud substrate (cf. Crimes et al., 1977). In view of the morphologically variable previously described examples occurring on single stratification planes, a combination of the above could be equally as feasible. Nevertheless, irrespective of its origin, the concentric ornament appears to be particularly developed in $B$. perata in comparison to other ichnospecies. Crimes et al. (1977) did mention that faint concentric ornament could rarely occur in $B$. hemispherica, although the holotype does not indicate this (see Crimes et al., 1977, p. 117, Plate 6c; Pemberton et al., 1988, p. 883, Fig. 8). Bergaueria radiata and $B$. langi do not exhibit concentric ornament; clearly, therefore, the possible presence of such ornament in $B$. perata is significant and the diagnosis is emended accordingly.

Finally, although Pemberton et al. (1988) suggested that $B$. perata is thinly lined, this is clearly an oversimplification and is perhaps why these authors omitted the criterion of lining in their diagnosis of the ichnospecies. Material here is obviously thinly lined as is that reported by several previous authors (e.g., Arai and McGugan, 1968). Other reports, however, have emphasized the absence of linings (e.g., Fürsich, 1974; Fillion and Pickerill,
1990). Evidently, therefore, the ichnospecies may be lined or unlined and the emended diagnosis incorporates this observation.

\section{DISCUSSION AND CONCLUSIONS}

Prantl $(1945,1946)$ remarked that the trace fossil Bergaueria represented the casts of burrows made by sea anenomes, which Alpert (1973) subsequently suggested, more specifically, to have been actinarians. Ethologically, two alternatives have been proposed. Seilacher (1956) and Alpert (1973) suggested they represent dwelling burrows (Domichnia) whereas Arai and McGugan (1969), Fürsich (1974) and Hakes (1976) interpreted them as resting traces (Cubichnia). As noted by Pemberton $e$ t al. (1988), however, both interpretations are probably correct, with lined specimens representing Domichnia and most unlined specimens Cubichnia. Burrow linings are an obvious requisite when mass sediment properties are such that in order for the producing organisms, in this case presumably actinarian anenomes, to maintain stability some reinforcement of the burrows are necessary. This, combined with the observation that specimens here are non-overlapping but all occur in close proximity, possibly a result of reproductive gregariousness, suggest they can best be interpreted as Domichnia.

Bergaueria and its various ichnospecies have been widely reported in strata of earliest Cambrian to Eocene age (Crimes, 1987; Pemberton and Jones, 1988) with most reports being from Cambrian rocks. Pemberton et al. (1988) list Precambrian recordings by Hofmann and Aitken (1979), Fedonkin (1981) and Crimes and Germs (1982); to this list must also be added Kumar et al. (1984) who recorded it from the Late Riphaean of the Himalayas. Of these recordings, however, the structures recorded by Hofmann and Aitken (1979, p. 164, Fig. 17c) only superficially resemble Bergaueria and were only questionably referred to the ichnogenus; indeed, even a nonbiologic origin was not ruled out by them. The specimens figured and described by Crimes and Germs (1982) are extremely small, only 1 to $5 \mathrm{~mm}$ in diameter, and more closely resemble Intrites Fedonkin, 1980, as subsequently noted by Crimes (1987) himself in his review of late Precambrian to early Cambrian trace fossils. Finally, the recordings by Fedonkin (1981) and Kumar et al. (1984) remain to be confirmed or otherwise, as they could equally represent the Nemiana - preservation of the body fossil Beltanelliformis (G.M. Narbonne, personal communication, see also Narbonne and Hofmann, 1987, who explain how to differentiate Bergaueria and Beltanelliformis). Thus, Precambrian recordings of Bergaueria are suspect and it is hardly surprising, therefore, that Crimes (1987) and Narbonne and Myrow (1988) regard it as a definitive Phanerozoic form.

Fig. 3. Bergaueria perata from the Silurian of Cape George, northeast mainland Nova Scotia. (a) View of basal surface of collected slab illustrating ventral surface of specimens (numbered 1 to 10) as described in main text. (b) More detailed view of specimen number 1 (upper left in (a)) illustrating a central dimple or depression which extends outwards across a smooth, unornamented area to a slightly elevated peripheral ridge and then downward into a contrentrically ornamented steeply-convex margin. (c) Cross-sectional view of specimens 1 and 4 illustrating massive burrow infill. Note concentric ornament in specimen 2. (d) Oblique view of collected slab illustrating concentric omament $(1,2,3)$, ventral dimples $(1,2)$ and elevated protruberance (3) of complete specimens and general view of truncated and incomplete specimens. 
Despite its obviously extensive stratigraphic range, Bergaueria has only previously been recorded once from Silurian strata, from the Upper Silurian (Ludlow) Leopold Formation of arctic Canada by Narbonne (1984). Because of poor preservation Narbonne (1984) only identified his material at the ichnogeneric level, though it is clear from his figure (Narbonne, 1984, p. 407, Fig. 6G) that the specimens possess concentric ornament and, because they are so unlike $B$. hemispherica, can perhaps be tentatively compared to $B$. perata. The recording herein, therefore, represents only the second report of Bergaueria and certainly the first of $B$. perat $a$ in Silurian strata. To my knowledge, no bergauerians of any age have previously been formally recorded from eastern Canada; the report by Arai and McGugan (1968) of Bergaueria in Lower Cambrian quartzites of the Labrador Group in western Newfoundland, and listed as such in Pemberton et al. (1988), remains to be confirmed as it was made in the form of a personal communication from Dr. S.J. Nelson.

\section{ACKNOWLEDGEMENTS}

John Hurst is thanked for help in collecting the sample. Helpful reviews of the initial manuscript were provided by D.C. Carter and B. Murphy. A. Gomez, R. McCulloch and R. Northrup provided excellent technical assistance. The research was undertaken during tenure of a Natural Sciences and Engineering Research Council of Canada grant A3857 which is gratefully acknowledged.

ALPERT, S.P. 1973. Bergaueria Prantl (Cambrian and Ordovician), a probable actinian trace fossil. Journal of Paleontology, 47, pp.919924.

ALPERT, S.P. and MOORE, J.N. 1975. Lower Cambrian trace fossil evidence for predation on trilobites. Lethaia, 8, pp. 223-230.

ARAI, M.N. and McGUGAN, A. 1968. A problematical coelenterate(?) from the Lower Cambrian, near Moraine Lake, Banff area, Alberta. Joumal of Paleontology, 42, pp. 205-209.

- 1969. A problematical Cambrian coelenterate(?). Journal of Paleontology, 43, pp. 93-94.

BANDEL, K. 1973. A new name for the ichnogenus Cylindrichnus Bandel, 1967. Journal of Paleontology, 47, p. 1002.

BOUCOT, A.J., DEWEY, J.F., DINELEY, D.L., FLETCHER, R., FYSON, W.K., GRIFFIN, J.G., HICKOX, C.F., McKERROW, W.S., and ZIEGLER, A.M. 1974. Geology of the Arisaig area, Antigonish County, Nova Scotia. Geological Society of America, Special Paper 139, 191 p.

BOYD, D.W. 1974. Wyoming specimens of the trace fossil Bergaueria. Contributions to Geology, 13, pp. 11-15.

CHAMBERLAIN, C.K. 1971. Morphology and ethology of trace fossils from the Ouachita Mountains, southeast Oklahoma. Journal of Paleontology, 45, pp. 212-246.

CRIMES, T.P. 1987. Trace fossils and correlation of late Precambrian and early Cambrian strata. Geological Magazine, 124, pp. 97-119.

CRIMES, T.P. and ANDERSON, M.M. 1985. Trace fossils from late Precambrian-early Cambrian strata of southeastern Newfoundland (Canada): temporal and environmental implications. Journal of Paleontology, 59, pp. 310-343.

CRIMES, T.P. and GERMS, G.J.B. 1982. Trace fossils from the Nama Group (Precambrian-Cambrian) of southwest Africa. Joumal of Paleontology, 46, pp. 890-907.

CRIMES, T.P., LEGG, I., MARCOS, A., and ARBOLEYA, M. 1977.
?Late Precambrian-low Lower Cambrian trace fossils from Spain. In Trace fossils 2. Edited by T.P. Crimes and J.C. Harper. Geological Journal, Special Issue 9. Seel House Press, Liverpool, pp. 91-138.

FEDONKIN, M.A. 1980. Fossil traces of Precambrian metazoa. Izvestiya Akademiya Nauk SSSR, Seriya Geologicheskaya, 8, pp. $39-46$.

- 1981. White Sea biota of the Vendian. Trudy Geologicheskogo Instituta, Akademiya Nauk SSSR, 342, 99 p.

FILLION, D. and PICKERILL, R.K. 1990. Ichnology of the Upper Cambrian(?) to Lower Ordovician Bell Island and Wabana groups of eastern Newfoundland, Canada. Palaeontographica Canadiana. In press.

FƯRSICH, F.T. 1974. Corallian (Upper Jurassic) trace fossils from England and Normandy. Stuttgarter Beiträge zur Naturkunde aus dem Staatlichen Museum für Naturkunde in Stuttgart, serie B, 13, pp. 1-52.

HAKES, W.G. 1976. Trace fossils and depositional environment of four clastic units, Upper Pennsylvanian megacyclothems, northeast Kansas. University of Kansas Paleontological Contributions, Article 63, $46 \mathrm{p}$.

HALDEMAN, S.S. 1840. Supplement to number one of "a monograph of the Limniades, or freshwater univalve shells of North America," containing descriptions of apparently new animals in different classes, and the names and characters of the subgenera in Paludina and Anculosa. Philadelphia, private publication, $3 \mathrm{p}$.

HALLAM, A. 1960. Kulundrichnus langi, a new trace fossil from the Lias. Palaeontology, 3, pp. 64-68.

HOFMANN, H.J. and AITKEN, J.D. 1979. Precambrian biota from the Little Dal Group, Mackenzie Mountains, northwestern Canada. Canadian Journal of Earth Sciences, 16, pp. 150-166.

KARASZEWSKI, W. 1971. Some fossil traces from the lower Liassic of the Holy Cross Mts., central Poland. Bulletin de l'Académie polonaise des sciences, Série des sciences de la terre, 19, pp. 101105.

KSIAZŻKIEWICZ, M. 1977. Trace fossils in the flysch of the Polish Carpathians. Palaeontologica polonica, 36, 208 p.

KUMAR, G., RAINA, B.K., BHARGAVA, O.N., MAITHY, P.K., and BABU, R. 1984. The Precambrian-Cambrian boundary problem and its prospects, Northwest Himalaya, India. Geological Magazine, 121, pp. 211-219.

LESQUEREUX, L. 1876. Species of fossil marine plants from the Carboniferous Measures. Geological Survey of Indiana, Annual Report 7, pp. 134-145.

MYANNIL, R.M. 1966. O vertikalnykh norkakh zaryvaniya v Ordvikskikh izrestiyakakh Pribaltiki. Akademiya Nauk SSSR, Paleontologicheskiy Institut, pp. 200-207.

NARBONNE, G.M. 1981. Stratigraphy, reef development and trace fossils of the Upper Silurian Douro Formation in the southeastern Canadian Arctic Islands. Unpublished Ph.D. dissertation, University of Ottawa, Ontario, $259 \mathrm{p}$.

- 1984. Trace fossils in Upper Silurian tidal flat to basin slope deposits of Arctic Canada. Joumal of Paleontology, 58, pp. 398. 415.

NARBONNE, G.M. and HOFMANN, H.J. 1987. Ediacaran biota of the Wernecke Mountains, Yukon, Canada. Palaeontology, 30, pp. 647-676.

NARBONNE, G.M. and MYROW, P. 1988. Trace fossil biostratigraphy in the Precambrian-Cambrian boundary interval. In Trace Fossils, Small Shelly Fossils and the Precambrian-Cambrian Boundary. Edited by E. Landing, G.M. Narbonne, and P. Myrow. University of the State of New York, New York State Museum/ 
Geological Survey, State Ėducation Department, Bulletin 463, pp. 72-76.

PEMBERTON, S.G. and JONES, B. 1988. Ichnology of the Pleistocene Ironshore Formation, Grand Cayman Island, British West Indies. Journal of Paleontology, 62, pp. 495-505.

PEMBERTON, S.G., FREY, R.W., and BROMLEY, R.G. 1988. The ichnotaxonomy of Conostichus and other plug-shaped ichnofossils. Canadian Journal of Earth Sciences, 25, pp. 866-892.

PRANTL, F. 1945. Dvé záhadné Zklamenéliny (stopy). z vrstev chrustenickch - d $\delta 2$, Rozpravy II. Tridy Ceské Akademie, 55, pp. 3-8.
1946. Two new problematic trails from the Ordovician of Bohemia. Academie Tchèque des Sciences, Bulletin International, Classe des Sciences Mathématiques, Naturelle et de la Medicine, 46. pp. 49-59.

RADWANSKI, A. and RONIEWICZ, P. 1963. Upper Cambrian trilobite ichnocoenosis from Wielka Wisniowka (Holy Cross Mountains, Poland). Acta Palaeontologica Polonica, 8, pp. 259. 280.

SEILACHER, A. 1956. Der Beginn des Kambriums als biologische Wende. Neues Jahrbuch für Geologie und Paläontologie, Abhandlungen, 103, pp. 155-180. 